\title{
Response of periphyton to nutrient addition in a tufa-depositing environment
}

\author{
Renata Matoničkin Kepčija ${ }^{1, *}$, Marko Miliša ${ }^{1}$, Mirela Sertić Perić ${ }^{1}$, \\ Marijana Matijić Cvjetović ${ }^{2}$, Biserka Primc-Habdija ${ }^{1}$ \\ ${ }^{1}$ Department of Zoology, Faculty of Science, University of Zagreb, Rooseveltov trg 6, 10000 Zagreb, Croatia \\ ${ }^{2}$ Sanitary Inspection, Ministry of Health and Social Welfare, Vukovarska 16, 20000 Dubrovnik, Croatia
}

\begin{abstract}
We examined the effects of added nutrients on primary producers, protozoans and meiofauna - as well as on tufa deposition - in a short-term in situ experiment using nutrientdiffusing substrata. The study was carried out in the tufa-depositing barrage lake system National Park Plitvice Lakes (Croatia). To address the question of whether the extent of tufa deposition and the flow velocity modify the response of periphyton to nutrient addition, we selected 2 sites - fast flow (FF) and slow flow (SF) - on each of the 2 barriers, one barrier having a low rate of tufa deposition (LTD) and the other having a high rate of tufa deposition (HTD). The nutrients examined were nitrogen $(\mathrm{N})$, phosphorus $(\mathrm{P})$, and their combination $(\mathrm{N}+\mathrm{P})$. Both $\mathrm{N}$ and $\mathrm{P}$ were limiting nutrients for autotrophs in periphyton, and the response to nutrient enrichment was lower at HTD sites. A combination of HTD and FF was the most limiting factor for periphyton. Nutrient enrichment did not impede calcite deposition; P enrichment even enhanced calcite deposition-probably as a result of a denser autotrophic periphyton matrix. HTD supported a lower taxa richness of heterotrophs in the periphyton, and flow velocity had taxa-specific effects. The addition of nutrients led to a decrease in the number of heterotrophic taxa at FF sites, while there was no effect at SF sites. The response of ciliates to flow velocity was taxa-specific. The effect of nutrients on the abundance of heterotrophs was rather weak, except for omnivorous and bacterivorous ciliates. Our results showed a direct effect of $\mathrm{N}$ and $\mathrm{P}$ on autotrophic periphyton in this tufa-depositing system, and only a weak effect on protozoans and micro-metazoans.
\end{abstract}

KEY WORDS: Flow velocity $\cdot$ Chlorophyll $a \cdot$ Protozoa $\cdot$ Nutrient limitation

\section{INTRODUCTION}

Very small benthic organisms, such as protozoans and metazoan meiofauna, are highly abundant and diverse components of stream communities; however, they are often overlooked owing to methodological difficulties (Reiss \& Schmid-Araya 2008). Protozoans are an important link in the microbial loop in the stream periphyton due to the effects of grazing, excretion and bioturbation (Pusch et al. 1998). Ciliates have high rates of growth, and their level of production in the benthos can exceed total invertebrate production (Finlay \& Esteban 1998).
Experiments involving the addition of nutrients have demonstrated that nitrogen $(\mathrm{N})$ and phosphorus (P) are dominant nutrients controlling the trophic states of streams and rivers (Dodds \& Welch 2000). Enrichment with $\mathrm{N}$ and $\mathrm{P}$ can determine whether there is a heterotrophic or an autotrophic state; these effects can also cascade up the food web (Dodds 2006). Artificial eutrophication decreases the diversity of microalgae (Hillebrand \& Sommer 2000) and increases bacterial abundance (Gray et al. 2006) and ciliate biomass (Wickham et al. 2004). Experimental eutrophication also increases the abundance of ciliates but, at the same time, decreases their diversity 
(Andrushchyshyn et al. 2006). Bernhardt \& Likens (2004) showed that eutrophication does not have an effect on the biomass of periphyton. To date, the effects of nutrient enrichment on protozoa have been examined in lakes (Hillebrand et al. 2002), rivers (Rublee \& Partusch-Talley 1995) and streams (Domènech et al. 2006). While weak effects of nutrient enrichment on ciliate biomass were reported by Hillebrand et al. (2002), Rublee \& Partusch-Talley (1995) observed a significant increase in the abundance and biomass of heterotrophic microfauna after the addition of $\mathrm{N}+\mathrm{P}$, but no significant difference after the addition of $\mathrm{P}$ alone. Domènech et al. (2006) attributed an increase in ciliate density to the addition of $\mathrm{N}+\mathrm{P}$, whereas flagellates and testate amoebae were reported to be less sensitive to nutrient enrichment.

Tufa develops under specific physico-chemical conditions as an ambient temperature freshwater carbonate deposit in which biological remains (particularly those of macrophyte stands) may comprise significant parts of deposited frameworks (Pedley 2000). Tufa formation is also responsible for increasing the habitat surface for diverse organisms (Pentecost 2005). The rough surface of the tufa-covered substrate provides greater microhabitat complexity, and it supports increased algal growth compared to sediment without encrustations (Kock et al. 2006). At sites of active tufa deposition this deposit is not only a substrate upon which periphyton develops: tufa is also embedded within the periphyton matrix, i.e. it becomes part of the structure of the matrix. Moreover, in places with high precipitation rates, calcite can actually bury the periphytic organisms (Pedley 2000).

Only rarely has the periphytic protozoan community of tufa-depositing systems been investigated (e.g. Primc-Habdija et al. 2001, 2005). Periphyton containing sedimentary autotrophs has been found to be strongly P-limited (Sabater et al. 2000, Elser et al. 2005a). Nutrient enrichment in calcifying environments may affect algal composition and C:P:N ratios (Elser et al. 2005a), and, at the same time, may control the growth and metabolism of grazing snails (Elser et al. 2005b). Inorganic P can slow calcite growth, and, at higher concentrations, even cause it to stop (Plant \& House 2002). Therefore, increased P levels might cause the disappearance of the tufa encrustation together with its associated communities (Pentecost \& Whitton 2000). Thus, eutrophy represents a major threat for tufa deposition (Sabater et al. 2000). To our knowledge, there has been no study on the effects of nutrient enrichment on protozoan communities in tufa-depositing environments.
Tufa barrages form barriers between karstic lakes and are hydrodynamically variable sites due to their geomorphological features. They represent places of high habitat diversity with patchy pool-riffle configurations. As the water carrying suspended particles overflows the barrier, the associated periphyton is affected by sedimentation, erosion and resuspension of bed particles. The overall outcome of these events will depend on flow velocity, turbulence and periphyton resistance. Flow velocity influences both the structure (Abe et al. 2000) and the composition of the periphyton community (Soininen 2004), and it might also determine the magnitude of the effect of nutrient enrichment on periphyton (Ghosh \& Gaur 1994). Flow conditions influence both the precipitation rate and the morphology of calcite deposits (Pedley \& Rogerson 2010).

In this study, we used nutrient-diffusing substrata during a short-term in situ experiment to assess the effects of nutrient addition on: (1) the primary producers (i.e. the algal response to nutrient enrichment), (2) the composition of the protozoan community, (3) the assemblages of metazoan meiofauna, and (4) the amount of tufa deposited. The experiment was carried out in 2 contrasting sites, one having a low rate of tufa deposition (LTD) and the other having a high rate of tufa deposition (HTD). Additionally, we tested the effect of flow velocity by selecting microhabitats of both slow flow (SF) and fast flow (FF) at both LTD and HTD sites. Our hypotheses were: (1) that the addition of nutrients increases the biomass of autotrophs in periphyton, (2) that the diversity of protozoa decreases with the increased supply of nutrients, (3) that the addition of $\mathrm{P}$ causes a decrease in tufa deposition, and (4) that flow velocity modifies the effect of nutrients on periphyton and on tufa deposition.

\section{MATERIALS AND METHODS}

\section{Study site}

The experiments were carried out during September and October 2006 on tufa barriers of the Plitvice Lakes, a Croatian barrage-lake system of 16 successive lakes that descend in a cascade from an altitude of $636 \mathrm{~m}$ above sea level to $503 \mathrm{~m}$ over a distance of $8.2 \mathrm{~km}$ (Fig. 1). The first location (Table 1) was on a barrier between the 10th and the 11th lake (Fig. 2) in the 'Upper Lakes' area, located in a broad valley. The basic rock masses consist of dolomite, from the Upper Triasic age (Polšak 1974), whose poor permea- 


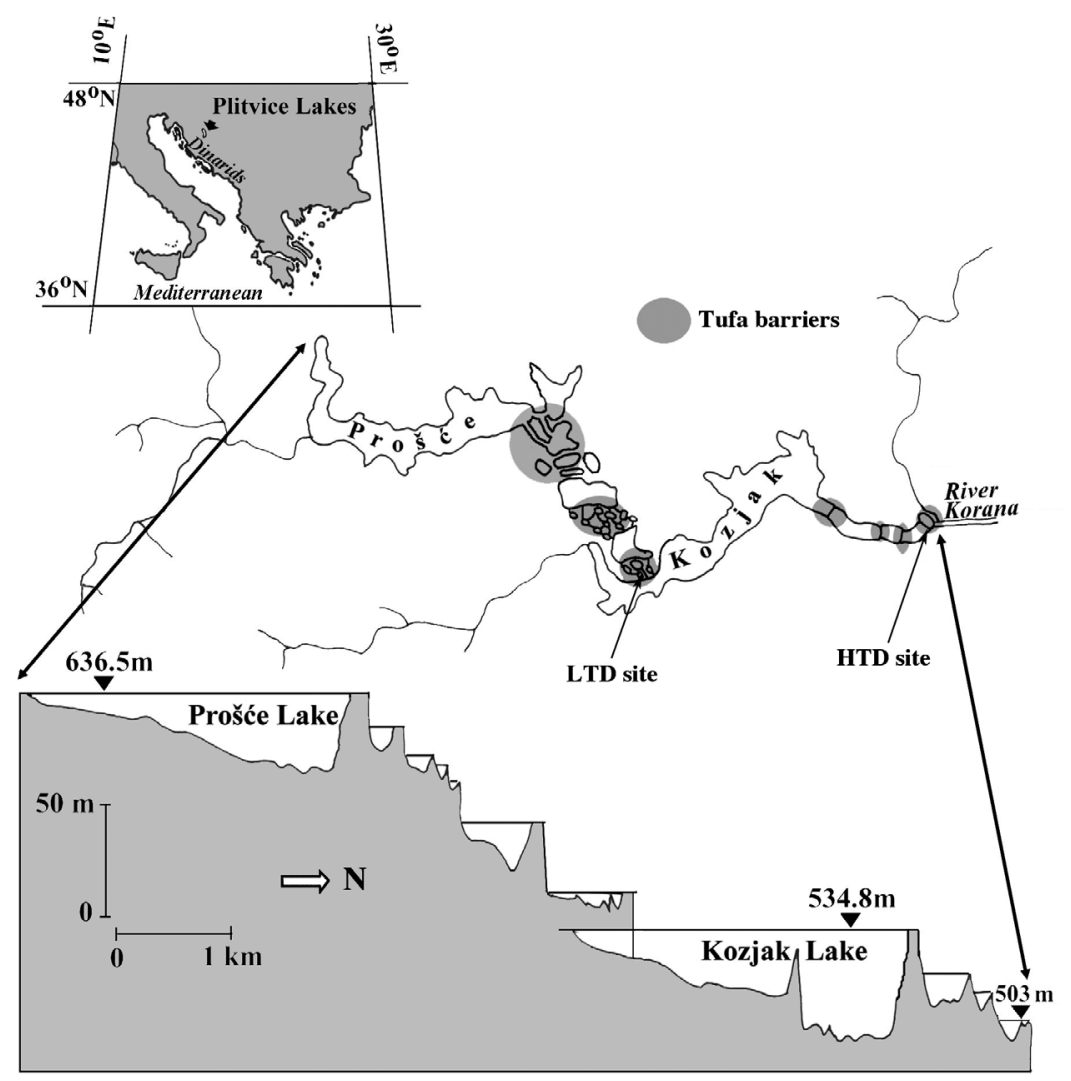

Fig. 1. Plitvice Lakes, Croatia, with the horizontal (middle) and vertical (bottom) profiles of barrage lakes and location of study sites. LTD = low tufa deposition, HTD = high tufa deposition

Table 1. Study site characteristics and average values $( \pm \mathrm{SD})$ of physical and chemical parameters of water during the study period. LTD = low tufadeposition rate, HTD = high tufa-deposition rate

\begin{tabular}{|c|c|c|}
\hline Parameter & LTD sites & HTD sites \\
\hline Latitude & $44^{\circ} 52^{\prime} 45^{\prime \prime} \mathrm{N}$ & $44^{\circ} 54^{\prime} 7^{\prime \prime} \mathrm{N}$ \\
\hline Longitude & $15^{\circ} 36^{\prime} 48^{\prime \prime} \mathrm{E}$ & $15^{\circ} 36^{\prime} 40^{\prime \prime} \mathrm{E}$ \\
\hline Altitude (m above sea level) & 553 & 504 \\
\hline Location in the barrage system & $\begin{array}{l}\text { Between 10th } \\
\text { and 11th lake }\end{array}$ & $\begin{array}{l}\text { Between 15th } \\
\text { and 16th lake }\end{array}$ \\
\hline $\begin{array}{l}\text { Dominant bryophyte } \\
\text { vegetation }\end{array}$ & $\begin{array}{l}\text { Cratoneurum } \\
\text { commutatum }\end{array}$ & $\begin{array}{l}\text { Cratoneurum } \\
\text { commutatum }\end{array}$ \\
\hline $\begin{array}{l}\text { Dominant macrophyte } \\
\text { vegetation }\end{array}$ & Petasites spp. & $\begin{array}{l}\text { Petasites spp., } \\
\text { Salix spp. }\end{array}$ \\
\hline Flow velocity $\left(\mathrm{cm} \mathrm{s}^{-1}\right)$ & $\begin{array}{l}\text { Fast: } 76 \pm 4 \\
\text { Slow: } 22 \pm 2\end{array}$ & $\begin{array}{l}\text { Fast: } 81 \pm 3 \\
\text { Slow: } 19 \pm 2\end{array}$ \\
\hline Water temperature $\left({ }^{\circ} \mathrm{C}\right)$ & $16.9 \pm 2.1$ & $17.8 \pm 2.3$ \\
\hline Dissolved oxygen $\left(\mathrm{mg} \mathrm{l}^{-1}\right)$ & $9.4 \pm 0.6$ & $9.1 \pm 0.4$ \\
\hline $\mathrm{pH}$ & $8.3 \pm 0.2$ & $8.4 \pm 0.2$ \\
\hline Alkalinity $\left(\mathrm{mg} \mathrm{CaCO}_{3} \mathrm{l}^{-1}\right.$ ) & $200 \pm 5$ & $190 \pm 5$ \\
\hline Nitrates $\left(\mu \mathrm{g} \mathrm{N} \mathrm{^{-1 } )}\right.$ & $23.5 \pm 7.4$ & $5.9 \pm 3.6$ \\
\hline Nitrites $\left(\mu g \mathrm{~N} \mathrm{l}^{-1}\right)$ & $0.7 \pm 0.5$ & $2.5 \pm 0.9$ \\
\hline Orthophosphates (mg P $1^{-1}$ ) & 0 & 0 \\
\hline Chemical oxygen demand $\left(\mathrm{mg} \mathrm{O}_{2} \mathrm{l}^{-1}\right)$ & $0.23 \pm 0.12$ & $0.47 \pm 0.11$ \\
\hline
\end{tabular}

bility has resulted in the formation of the Upper Lakes (Biondić et al. 2010). This area has a relatively low rate of tufa deposition (Srdoč et al. 1985), reported to be in the range of 0 to $0.45 \mathrm{mg} \mathrm{dm}^{-2} \mathrm{~d}^{-1}$, depending on season (Matoničkin Kepčija et al. 2005). The second location (Table 1) was on the barrier between the last 2 lakes of the system (Fig. 2), in the 'Lower Lakes' area, positioned in a deep canyon cut into massive rudist limestone from the Jurassic age (Polšak 1974). The rate of tufa deposition at this site is high, ranging from $0.13 \mathrm{mg}$ $\mathrm{dm}^{-2} \mathrm{~d}^{-1}$ in winter to $13.77 \mathrm{mg} \mathrm{dm}-2$ $\mathrm{d}^{-1}$ in summer (Matoničkin Kepčija et al. 2005).

Two sites were chosen on each of the 2 barriers, 1 site with FF and 1 site with SF velocity (Table 1). Sampling sites were abbreviated as LTDFF (low tufa deposition-FF velocity), LTD-SF (low tufa deposition-SF velocity), HTD-FF (high tufa deposition-FF velocity) and HTD-SF (high tufa deposition-SF velocity).

\section{Experimental design, sampling and processing}

Tray samplers, modified from Biggs \& Kilroy (2000), were constructed to resist fluctuations in flow. The wooden frame was weighted with two bricks at each side (Fig. 3). Each tray sampler held 24 plastic nutrient-diffusing containers (200 ml) filled with agar. Four treatments were used (6 replicates of each): (1) control (2\% agar), (2) N-enriched (2\% agar, $0.5 \mathrm{M} \mathrm{NaNO}_{3}$ ), (3) Penriched $(2 \%$ agar and $0.05 \mathrm{M}$ $\mathrm{Na}_{3} \mathrm{PO}_{4} \cdot 12 \mathrm{H}_{2} \mathrm{O}$ ), and (4) $\mathrm{N}$ and $\mathrm{P}$ combined ( $2 \%$ agar, $0.5 \mathrm{M} \mathrm{NaNO}_{3}, 0.05 \mathrm{M}$ $\mathrm{Na}_{3} \mathrm{PO}_{4} \cdot 12 \mathrm{H}_{2} \mathrm{O}$ ). Surfaces for periphyton colonization (Whatman hardened ashless filter papers 541) were placed over the top of the containers and secured with the lid. In each container, the surface of the nutrient-diffusing substrata (NDS) that was exposed to water was $25 \mathrm{~cm}^{2}$. One tray sampler 
A

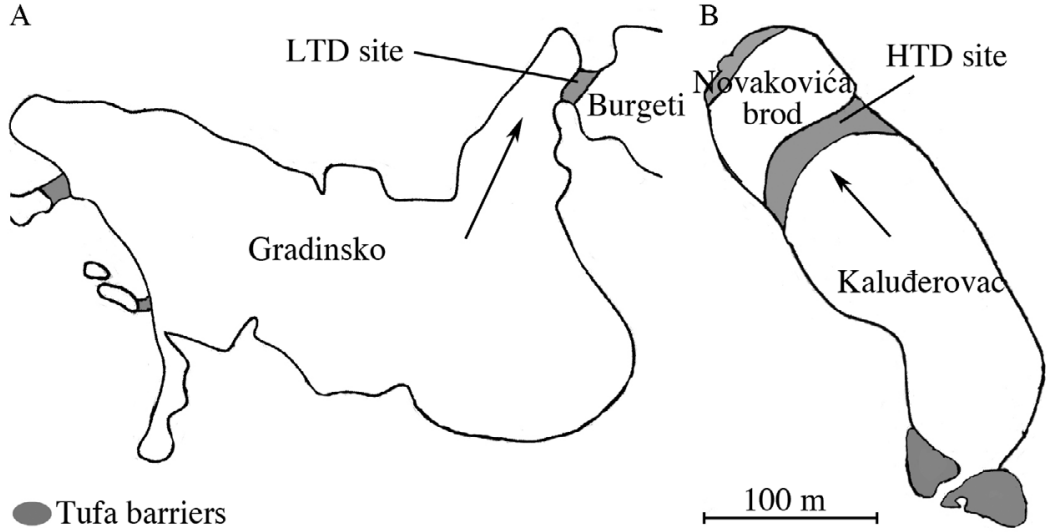

Fig. 2. Study sites on tufa barriers in the Plitvice Lakes National Park, Croatia. (A) Low tufa deposition (LTD) site on a barrier between Gradinsko Lake and Burgeti Lake. (B) High tufa deposition (HTD) site on a barrier between Kalu erovac Lake and Novakovića brod Lake. Arrows indicate the direction of water flow

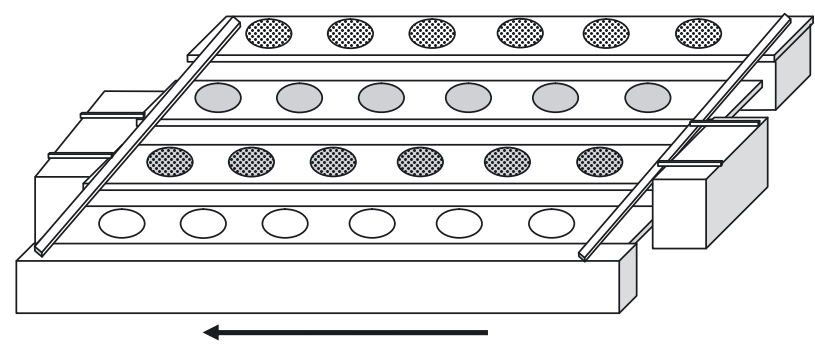

Fig. 3. Wooden tray samplers (schematic). The frame was weighted with two bricks at each end to ensure resistance to the flow of water. Different patterns of exposed surfaces indicate diverse nutrients; the arrow indicates the direction of water flow

was placed at each site (4 samplers and 96 nutrientdiffusing containers in total), at a water depth of $20 \mathrm{~cm}$.

An incubation time of $3 \mathrm{wk}$ was chosen, with a constant nutrient-diffusion rate from the NDS (Tank et al. 2006). After $3 \mathrm{wk}$ of incubation, the samplers were retrieved and filter papers were transferred to plastic vials containing ambient water. The vials were stored in a cool box and transported to the laboratory where they were analyzed within $24 \mathrm{~h}$. Temperature, dissolved oxygen, conductivity and $\mathrm{pH}$ were measured in the field using a field multi-parameter probe Multi340i (WTW). Flow velocity was measured with the flow-velocity meter SWOFFER 3000 (Swoffer Instruments). Alkalinity, total hardness, chemical oxygen demand and nutrient concentrations were determined in the laboratory (according to APHA 1985). All analyses were performed at the beginning and at the end of the exposure. Containers (4 replicates) with agar were placed in $200 \mathrm{ml}$ of distilled water for $2 \mathrm{~h}$, followed by an analysis of nitrates and phosphates in the water, to test the availability of nutrients after $3 \mathrm{wk}$ of exposure. Subsamples for the analysis of protozoan and metazoan composition were taken by scraping a $1 \mathrm{~cm}^{2}$ area from each filter paper ( 3 replicate filter papers were taken). These subsamples were transferred to glass slides and suspended in a small amount of ambient water before examination under the microscope. Living protozoans and metazoans were identified to at least genus level, where possible, using appropriate literature (Kahl 1930-1935, Donner 1965, Koste 1978, Foissner et al. 1991, Page 1991, Foissner 1992, 1994, 1995). Ciliates were classified into feeding types according to information in Foissner et al. (1991, 1992, 1994, 1995) and Lynn (2008).

Three replicates were processed for their content of chlorophyll a ( $\mathrm{chl} a, \mathrm{mg} \mathrm{cm}^{-2}$ ) according to the ethanol extraction procedure of Nusch (1980). The content of organic matter (ash-free dry weight, AFDW) of the samples was determined based on the method of drying $\left(1 \mathrm{~d}\right.$ at $\left.105^{\circ} \mathrm{C}\right)$ and weighing followed by combustion in a muffle furnace $(4 \mathrm{~h}$ at $450^{\circ} \mathrm{C}$ ) and re-weighing. For that procedure, we used the 3 replicates remaining from the analysis of periphyton composition. Therefore, before calculating the content of organic matter, $1 \mathrm{~cm}^{2}$ was taken from the original surface.

Tufa deposition was estimated after dissolution of the combusted samples with hydrochloric acid, followed by rinsing, drying and weighing of the residues. Both parameters (i.e. organic matter content and tufa deposition) were determined as mass per unit area. The algal response to the addition of nutrients was calculated from chl $a$ as the logarithmic ratio of the treatment relative to the control (Tank \& Dodds 2003).

All samples containing $\mathrm{P}$ (5 P replicates and $5 \mathrm{~N}+\mathrm{P}$ replicates) were destroyed at site HTD-SF, possibly because of interference by the freshwater crayfish Austropotamobius torrentium.

\section{Data analysis}

Data were analysed using Statistica 8.0 (StatSoft 2007). A non-parametric Mann-Whitney $U$-test was used to compare the diffusion rates of nutrients. Correlations between measured variables (calcite, con- 
centration of chl $a$ and AFDW) were tested using a Spearman rank correlation coefficient. The same measure was used to explore relationships between those variables and the number of taxa and abundance of protozoa and micro-metazoa.

Due to the loss of 1 set of samples, the experiment had an unbalanced design structure. To bypass the problem of missing cells in analysis of variance (ANOVA), we analyzed subsets of the data with observations in all cells (Quinn \& Keough 2002). There were 2 missing cells ( $\mathrm{P}$ and $\mathrm{P}+\mathrm{N}$ samples from the HTD-SF site) within 16 possible combinations of 3 factors. Two-way and 3-way ANOVA tests were used to compare calcite, concentration of chl $a$, AFDW, the number of taxa and the abundance of protozoa and micro-metazoa with tufa deposition, flow velocity and nutrients as factors. Three-way ANOVA was used to analyze the data for control and $\mathrm{N}$ treatments only. Two-way ANOVAs were used for 2 subsets. The first subset was created by omitting the data in SF, thus enabling us to test the effects of tufa deposition and nutrients on periphyton parameters. The other subset comprised the data from LTD sites only, providing the analysis of flow velocity and nutrient effects. Tukey HSD was used for post hoc comparisons. The normality of data was tested using the Shapiro-Wilks $W$-test. When necessary, logarithmic transformations were applied to meet a parametric assumption of normality.

To compare the community structure of samples, a Bray-Curtis similarity coefficient matrix was calculated on root-transformed data of taxa abundances (sample replicates were averaged prior to analysis). This matrix was used for non-metric multidimensional scaling (nMDS) to visualize possible grouping of sites and/or treatments.

\section{RESULTS}

Nutrients were slightly more depleted from the containers in $\mathrm{FF}$, the difference being more pronounced at the HTD site for both nutrients (Table 2). Statistically significant differences were found only for P between sites HTD-SF and HTD-FF (MannWhitney $U$-test, $\mathrm{p}<0.01$ )

The mean tufa deposition was $2.02 \mathrm{mg} \mathrm{cm}^{-2}$; it ranged from $0.36 \mathrm{mg} \mathrm{cm}^{-2}$ in the control treatment at the LTD-SF site to $8.40 \mathrm{mg} \mathrm{cm}^{-2}$ in the control treatment at the HTD-SF site. As expected, tufa deposition differed between barriers and between current velocities (Table 3). The interaction of those 2 factors was also significant; post hoc testing separated tufa deposition at the HTD-SF site from deposition at all the other sites (Tukey HSD, p < 0.001), while other values were not significantly different (Fig. 4). The effect of nutrients on tufa deposition was significant only as a 3-way interaction with tufa deposition and flow velocity (Table 3 ). Analysis of the FF subset, however, showed significant differences in the amount of calcite deposition between nutrient treatments (Table 4); it was higher on Penriched substrata compared to controls (Tukey HSD, $\mathrm{p}<0.05$ ). The 2-way ANOVA for the LTD subset indicated a possible effect of nutrients on tufa deposition (Table 5), with post hoc testing separating the amount of tufa between all treatments (Tukey HSD, $\mathrm{p}<0.01$ ) except $\mathrm{P}$ and $\mathrm{P}+\mathrm{N}$ (Tukey HSD, $\mathrm{p}>0.05$ ).

The average concentration of chl a was $0.16 \mu \mathrm{g}$ $\mathrm{cm}^{-2}$. In contrast to patterns of tufa deposition, accrual of chl a was significantly higher at LTD sites (Fig. 4). ANOVA also separated chl a results between flow habitats, as well as between control and N-enriched substrata (Table 3). Regarding the effect on chl $a$ of tufa deposition $\times$ Flow velocity, the HTD-FF site had significantly lower concentrations (Fig. 4). Nitrates $\times$ Tufa deposition also had an effect, with nitrate-enriched substrata at LTD having higher concentrations of chl a compared to other combinations (Tukey HSD, $p<0.01$ for all combinations). The effect of $\mathrm{P}$ was evident from the fast-current subset analyses (Table 4) which separated Pand $\mathrm{N}+\mathrm{P}$-enriched substrata from control substrata $(p<0.05)$. Nutrients were also significant in the analysis of the LTD subset (Table 5). The mean algal response (log[treatment $\mathrm{chl}$ a/control $\mathrm{chl}$ a]) was highest for P-enriched substrata $(0.51 \pm 0.23)$, and

Table 2. Average diffusion rates of nutrients $( \pm \mathrm{SD})$ at the start of the experiment and after $3 \mathrm{wk}$ of exposure. LTD $=$ low tufa-deposition rate; HTD = high tufa-deposition rate

\begin{tabular}{|c|c|c|c|c|c|}
\hline \multirow{2}{*}{$\begin{array}{l}\text { Nutrient } \\
\text { (diffusion rate) }\end{array}$} & \multirow[t]{2}{*}{ Start } & \multicolumn{2}{|c|}{- LTD -} & \multicolumn{2}{|c|}{ HTD } \\
\hline & & Slow & Fast & Slow & Fast \\
\hline 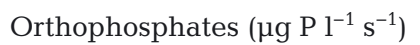 & $2.88 \pm 0.07$ & $2.51 \pm 0.36$ & $2.47 \pm 0.03$ & $2.62 \pm 0.10$ & $2.28 \pm 0.40$ \\
\hline Nitrites $\left(\mu g \mathrm{~N}^{-1} \mathrm{~s}^{-1}\right)$ & $9.08 \pm 0.03$ & $8.98 \pm 0.10$ & $8.92 \pm 0.01$ & $9.00 \pm 0.01$ & $8.92 \pm 0.02$ \\
\hline
\end{tabular}


Table 3. Three-way ANOVA results for the effects of tufa deposition (TD), flow velocity and nitrates on periphyton parameters (all log-transformed except taxa richness). SS = sum of squares, $\mathrm{df}=$ degrees of freedom. Bold $\mathrm{p}$-values indicate statistical significance. AFDW = ash-free dry weight

\begin{tabular}{|c|c|c|c|c|}
\hline & SS & df & $F$ & $\mathrm{p}$ \\
\hline \multicolumn{5}{|l|}{ Calcite } \\
\hline TD & 4.4207 & 1 & 113.38 & 0.0000 \\
\hline Flow velocity & 1.0722 & 1 & 27.5 & 0.0001 \\
\hline Nitrates & 0.0076 & 1 & 0.194 & 0.6665 \\
\hline TD $\times$ Flow velocity & 1.3713 & 1 & 35.17 & 0.0002 \\
\hline TD $\times$ Nitrates & 0.1232 & 1 & 3.16 & 0.0945 \\
\hline Flow velocity $\times$ Nitrates & 0.0008 & 1 & 0.02 & 0.8778 \\
\hline TD $\times$ Flow velocity $\times$ Nitrates & 0.2647 & 1 & 6.79 & 0.0191 \\
\hline Residuals & 0.6238 & 16 & & \\
\hline \multicolumn{5}{|l|}{ Chlorophyll a } \\
\hline $\mathrm{TD}$ & 0.1843 & 1 & 5.52 & 0.0319 \\
\hline Flow velocity & 0.7747 & 1 & 23.21 & 0.0002 \\
\hline Nitrates & 0.3495 & 1 & 10.47 & 0.0052 \\
\hline TD $\times$ Flow velocity & 0.5167 & 1 & 15.48 & 0.0012 \\
\hline TD $\times$ Nitrates & 0.4323 & 1 & 12.95 & 0.0024 \\
\hline Flow velocity $\times$ Nitrates & 0.0083 & 1 & 0.25 & 0.6269 \\
\hline TD $\times$ Flow velocity $\times$ Nitrates & 0.0010 & 1 & 0.03 & 0.8749 \\
\hline Residuals & 0.5341 & 16 & & \\
\hline \multicolumn{5}{|l|}{ AFDW } \\
\hline $\mathrm{TD}$ & 0.1803 & 1 & 1.94 & 0.1823 \\
\hline Flow velocity & 0.4692 & 1 & 5.05 & 0.0390 \\
\hline Nitrates & 0.0056 & 1 & 0.06 & 0.8076 \\
\hline TD $\times$ Flow velocity & 0.0372 & 1 & 0.40 & 0.5354 \\
\hline TD $\times$ Nitrates & 0.0019 & 1 & 0.02 & 0.8877 \\
\hline Flow velocity $\times$ Nitrates & 0.1849 & 1 & 1.99 & 0.1773 \\
\hline TD $\times$ Flow velocity $\times$ Nitrates & 0.0242 & 1 & 0.26 & 0.6170 \\
\hline Residuals & 1.4867 & 16 & & \\
\hline \multicolumn{5}{|l|}{ Taxa richness } \\
\hline TD & 108.79 & 1 & 4.56 & 0.0485 \\
\hline Flow velocity & 228.79 & 1 & 9.59 & 0.0069 \\
\hline Nitrates & 56.78 & 1 & 2.38 & 0.1423 \\
\hline TD $\times$ Flow velocity & 617.67 & 1 & 25.89 & 0.0001 \\
\hline TD $\times$ Nitrates & 0.24 & 1 & 0.01 & 0.9103 \\
\hline Flow velocity $\times$ Nitrates & 42.47 & 1 & 1.78 & 0.2005 \\
\hline TD $\times$ Flow velocity $\times$ Nitrates & 15.03 & 1 & 0.63 & 0.4393 \\
\hline Residuals & 381.72 & 16 & & \\
\hline \multicolumn{5}{|l|}{ Abundance } \\
\hline TD & 1.2762 & 1 & 1.35 & 0.2620 \\
\hline Flow velocity & 2.7227 & 1 & 2.88 & 0.1090 \\
\hline Nitrates & 2.3918 & 1 & 2.53 & 0.1311 \\
\hline TD $\times$ Flow velocity & 10.5975 & 1 & 11.21 & 0.0041 \\
\hline TD $\times$ Nitrates & 0.0284 & 1 & 0.03 & 0.8580 \\
\hline Flow velocity $\times$ Nitrates & 0.0189 & 1 & 0.02 & 0.8883 \\
\hline $\mathrm{TD} \times$ Flow velocity $\times$ Nitrates & 5.1428 & 1 & 5.44 & 0.0330 \\
\hline Residuals & 15.1258 & 16 & & \\
\hline
\end{tabular}

lowest for $\mathrm{N}$-enriched substrata $(0.24 \pm 0.22)$. The mean algal response was lower in SF locations $(0.23$ $\pm 0.33)$ compared with FF locations (0.43 \pm 0.25$)$. There were also differences between LTD sites $(0.47 \pm 0.28)$ and HTD sites $(0.17 \pm 0.23)$, with the former having a greater algal response in all cases for the same flow velocity and treatment, suggesting a possible effect of tufa deposition on the magnitude of response to nutrient addition.
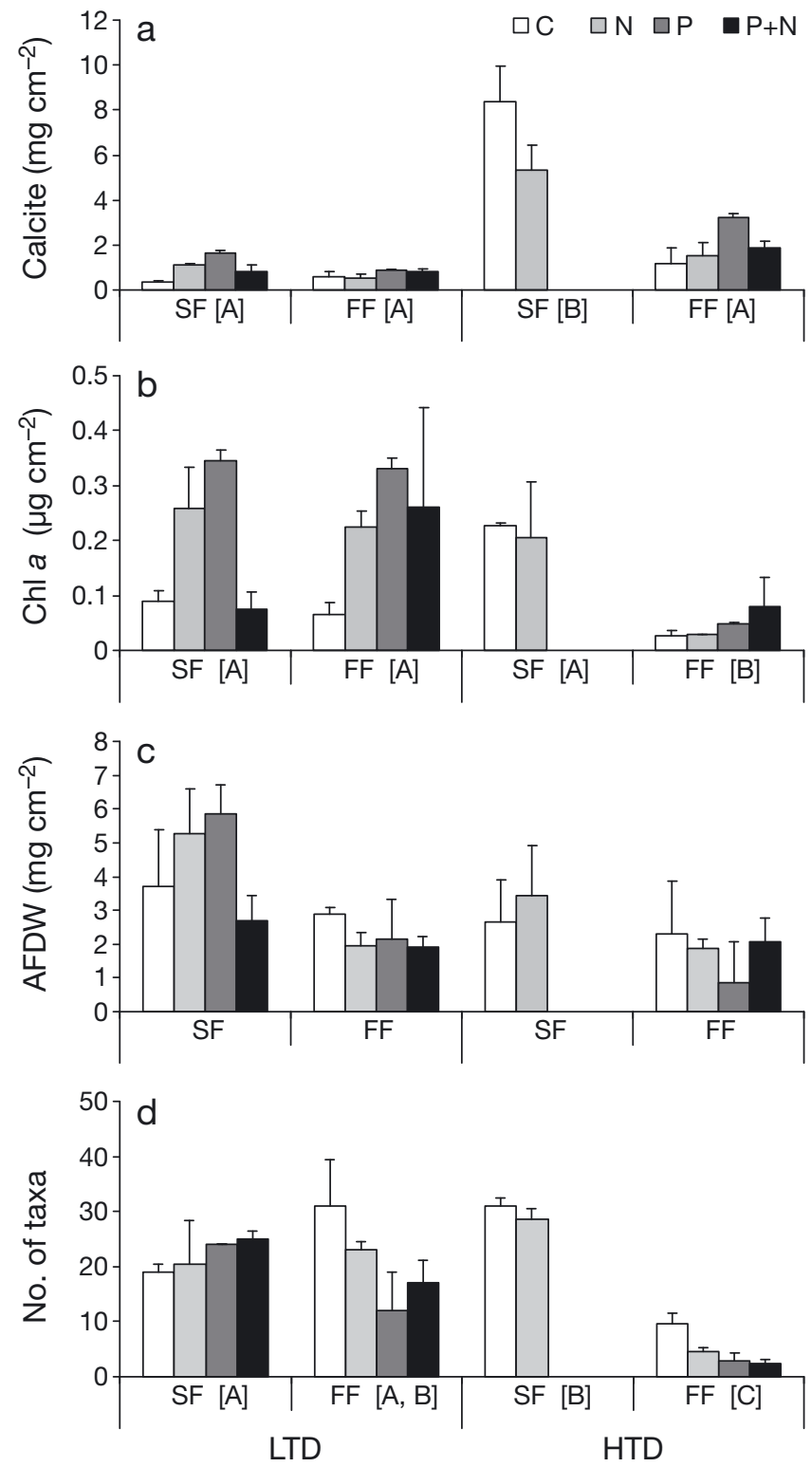

Fig. 4. (a) Deposited tufa (as calcite), (b) chlorophyll a, (c) ash-free dry weight (AFDW) of periphyton, and (d) number of taxa (mean of 3 replicates $\pm \mathrm{SD}$ ) at 2 study sites (low tufa deposition: LTD; high tufa deposition: HTD) with 2 rheotopes (slow flow: $\mathrm{SF}_{\text {; }}$ fast flow: $\mathrm{FF}$ ) and 4 treatments (control: $\mathrm{C}_{\text {; }}$ phosphorus added: $\mathrm{P}$; nitrogen added: $\mathrm{N}_{\text {; }}$ phosphorus and nitrogen added: $\mathrm{P}+\mathrm{N}$ ). Letters in square brackets refer to post hoc Tukey test results following ANOVA between TD $\times$ Flow velocity treatments (for ANOVA results refer to Table 3); groups with the same letter were not significantly different $(p>0.05)$

Flow velocity was significant as the main effect on periphyton organic matter (Tables 3 \& 5). On average, $3.9 \mathrm{mg} \mathrm{cm}^{-2}$ of AFDW were found in sites with SF compared to $2.0 \mathrm{mg} \mathrm{cm}^{-2}$ in FF sites. There was no trend towards higher concentration on enriched sub- 
Table 4. Two-way ANOVA results for the effects of tufa deposition (TD) and nutrients on periphyton parameters (all log-transformed except taxa richness) in fast current. SS = sum of squares, $\mathrm{df}=$ degrees of freedom. Bold $\mathrm{p}$-values indicate statistical significance. AFDW = ash-free dry weight

\begin{tabular}{|lcccc|}
\hline & SS & df & $F$ & $\mathrm{p}$ \\
\hline Calcite & & & & \\
TD & 0.8081 & 1 & 23.22 & $\mathbf{0 . 0 0 0 2}$ \\
Nutrients & 0.4479 & 3 & 4.29 & $\mathbf{0 . 0 2 1 1}$ \\
TD $\times$ Nutrients & 0.1660 & 3 & 1.59 & 0.2299 \\
Residuals & 0.5569 & 16 & & \\
Chlorophyll a & & & & \\
TD & 1.6271 & 1 & 22.15 & $\mathbf{0 . 0 0 0 2}$ \\
Nutrients & 0.8661 & 3 & 3.93 & $\mathbf{0 . 0 2 8 1}$ \\
TD $\times$ Nutrients & 0.4782 & 3 & 2.17 & 0.1311 \\
Residuals & 1.1753 & 16 & & \\
AFDW & & & & \\
TD & 0.1592 & 1 & 1.23 & 0.2838 \\
Nutrients & 0.3999 & 3 & 1.03 & 0.4036 \\
TD $\times$ Nutrients & 0.2640 & 3 & 0.68 & 0.5788 \\
Residuals & 2.0708 & 16 & & \\
Taxa richness & & & & \\
TD & 748.14 & 1 & 26.54 & $\mathbf{0 . 0 0 0 1}$ \\
Nutrients & 406.77 & 3 & 4.81 & $\mathbf{0 . 0 1 4 2}$ \\
TD $\times$ Nutrients & 120.08 & 3 & 1.42 & 0.2721 \\
Residuals & 451.02 & 16 & & \\
Abundance & & & & \\
TD & 12.45 & 1 & 6.7 & $\mathbf{0 . 0 1 9 8}$ \\
Nutrients & 11.82 & 3 & 2.12 & 0.1377 \\
TD $\times$ Nutrients & 5.18 & 3 & 0.93 & 0.4498 \\
Residuals & 29.73 & 16 & & \\
\hline & & & & \\
\hline
\end{tabular}

strata, except at LTD sites (Table 4), but only for Nand P-enriched substrata in SF (Fig. 4). AFDW and chl $a$ were positively correlated (Spearman's $\mathrm{R}=0.41$, $\mathrm{p}=0.002)$.

A total of 94 consumer taxa (protozoans and meiofauna) were identified, of which 69 were ciliate species or morphotypes and 12 amoeboid protozoans. Only 38 ciliate taxa and 9 amoeboid types were found at both LTD and HTD sites. Site-specific ciliate taxa were mostly those with low abundance, except for Holosticha sp., Urostyla grandis, Bursaridium pseudobursaria and Metacineta sp., which were abundant at LTD sites, and Vorticella picta which had dense populations at HTD sites. Seven taxa of rotifers were identified on both barriers, while other groups of meiofauna (Turbellaria, Gastrotricha, Nematoda, Oligochaeta, Cladocera and Ostracoda) were rare.

The mean number of protozoan and meiofaunal taxa per substrate was 23 ; it varied from 3 at the HTD-FF site to 31 at control sites of both LTD-FF and HTD-SF. The strongest effect on the number of consumer taxa was a 2-way interaction of tufa deposition $\times$ Flow velocity, with a post hoc test separating the HTD-FF site from other sites, as well as the HTD-SF
Table 5. Two-way ANOVA results for the effects of flow velocity and nutrients on periphyton parameters (all log-transformed except taxa richness) at a low tufa-deposition (LTD) site. SS = sum of squares, $\mathrm{df}=$ degrees of freedom. Bold $\mathrm{p}$-values indicate statistical significance. AFDW = ash-free dry weight

\begin{tabular}{|c|c|c|c|c|}
\hline & SS & $\mathrm{df}$ & $F$ & $\mathrm{p}$ \\
\hline \multicolumn{5}{|l|}{ Calcite } \\
\hline Flow velocity & 0.0883 & 1 & 28.097 & 0.0001 \\
\hline Nutrients & 0.5194 & 3 & 55.085 & 0.0000 \\
\hline Flow velocity $\times$ Nutrients & 0.2655 & 3 & 28.155 & 0.0000 \\
\hline Residuals & 0.0503 & 16 & & \\
\hline \multicolumn{5}{|l|}{ Chlorophyll a } \\
\hline Flow velocity & 0.0621 & 1 & 2.748 & 0.1169 \\
\hline Nutrients & 2.7800 & 3 & 41.034 & 0.0000 \\
\hline Flow velocity $\times$ Nutrients & 0.6627 & 3 & 9.782 & 0.0007 \\
\hline Residuals & 0.3613 & 16 & & \\
\hline \multicolumn{5}{|l|}{ AFDW } \\
\hline Flow velocity & 2.2577 & 1 & 63.232 & 0.0000 \\
\hline Nutrients & 0.8277 & 3 & 7.728 & 0.0021 \\
\hline Flow velocity $\times$ Nutrients & 1.1594 & 3 & 10.824 & 0.0004 \\
\hline Residuals & 0.5713 & 16 & & \\
\hline \multicolumn{5}{|l|}{ Taxa richness } \\
\hline Flow velocity & 7.59 & 1 & 0.5884 & 0.4542 \\
\hline Nutrients & 170.53 & 3 & 4.4044 & 0.0193 \\
\hline Flow velocity $\times$ Nutrients & 495.28 & 3 & 12.7918 & 0.0002 \\
\hline Residuals & 206.50 & 16 & & \\
\hline \multicolumn{5}{|l|}{ Abundance } \\
\hline Flow velocity & 0.2703 & 1 & 1.417 & 0.2513 \\
\hline Nutrients & 2.3750 & 3 & 4.149 & 0.0236 \\
\hline Flow velocity $\times$ Nutrients & 6.3974 & 3 & 11.175 & 0.0003 \\
\hline Residuals & 3.0533 & 16 & & \\
\hline
\end{tabular}

from the LTD-SF site (Fig. 4). Nutrients were significant only in the analysis of the FF subset (Table 4), with a post hoc test separating $\mathrm{P}$ - and $\mathrm{N}+\mathrm{P}$-enriched substrata from control substrata (Tukey HSD, p < 0.05). Protozoan and meiofauna taxa richness was lower on enriched substrata compared to control (Fig. 4) and showed a positive correlation with chl a (Spearman's $\mathrm{R}=0.47, \mathrm{p}=0.0003$ ) as well as with AFDW (Spearman's R $=0.45, p=0.001$ ). A significant effect of nutrients at LTD sites (Table 5) showed an opposite trend between SF and FF (Fig. 4), and post hoc testing separated only control from P-enriched substrata (Tukey HSD, $\mathrm{p}<0.05$ ).

As for taxa richness, the 2-way interaction of tufa deposition and flow velocity had the strongest effect on the abundance of protozoa and small metazoa in the periphyton. High tufa deposition and FF velocity were again the most restrictive factors, i.e. they supported the lowest number of individuals (Fig. 5). There was neither a statistically significant effect nor a recognizable trend associated with nutrient addition, except at LTD sites (Table 5), but only between $\mathrm{P}$ and $\mathrm{P}+\mathrm{N}$ substrata (Tukey HSD, $\mathrm{p}<0.05$ ), with the opposite situation between flow velocities (Fig. 5). 
Control substrata had surprisingly similar abundances of protozoa and small metazoa; however, they showed high within-replicate variance. The highest number of individuals was recorded on an N-enriched substrate at an LTD-FF site $\left(196\right.$ ind $\left.\mathrm{cm}^{-2}\right)$, and the lowest was on a $\mathrm{P}+\mathrm{N}$-enriched substrate at an HTDFF site (4 ind. $\mathrm{cm}^{-2}$ ).

The composition of the periphyton community differed between the HTDFF site and other sites, with communities on enriched substrata being more similar to one another than to control sites (Fig. 6). The communities on P-enriched substrata at the LTD-FF site were also separated from other LTD sites, due to lower taxa number (Figs. 4 \& 6). Control substrata generally did not differ from enriched substrata at LTD-SF and LTDFF sites.

Among analyzed groups, the greatest number of individuals belonged to the Ciliophora (Fig. 5), which accounted for 46.0 to $97.8 \%$ of the total abundance. A particularly high proportion of ciliates was found at the HTD-FF site. Rotifers were the second most abundant group, followed by amoeboid protozoans (17.8 and $11.9 \%$ of the total abundance, respectively). Other metazoan groups were sparse $(<2.0 \%$ at all sites). Among ciliates, members of the Hymenostomata and Hypotrichia dominated in both diversity and density (Fig. 5); they accounted for a mean of $69.7 \%$ of the total abundance of ciliates across all sites. Among hymenostomats, Cinetochilum margaritaceum, Cyclidium glaucoma and Glaucoma scintillans had an approximately 20-fold higher density at LTD sites compared to HTD sites, while Colpidium colpoda preferred HTD sites (10-fold higher density at HTD sites). Hypotrichs generally preferred LTD sites. Cyrtophorids (mainly Chilodonella uncinata) had the highest proportions at HTD-FF sites, and, accordingly, their abundance had a positive correlation with the deposited tufa (Spearman's R $=0.39, \mathrm{p}=0.003)$. The effect of tufa deposition on all other ciliate groups
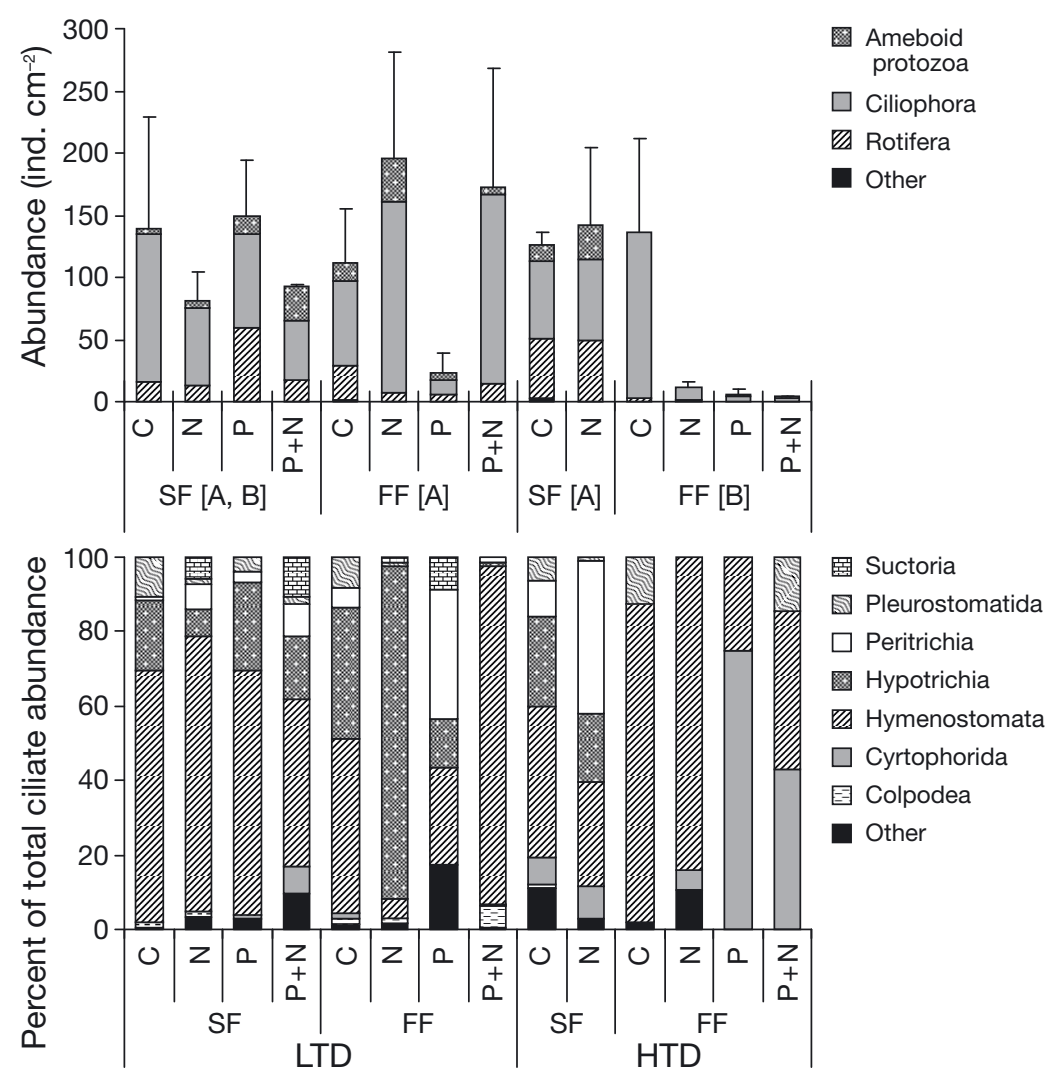

Fig. 5. Abundance (mean of 3 replicates \pm SD) of amoeboid protozoans, ciliates, rotifers and other micro-metazoans, and composition of the ciliate assemblages on nutrient-diffusing substrata. For the meanings of abbreviations, and of the letters in square brackets, see the legend of Fig. 4

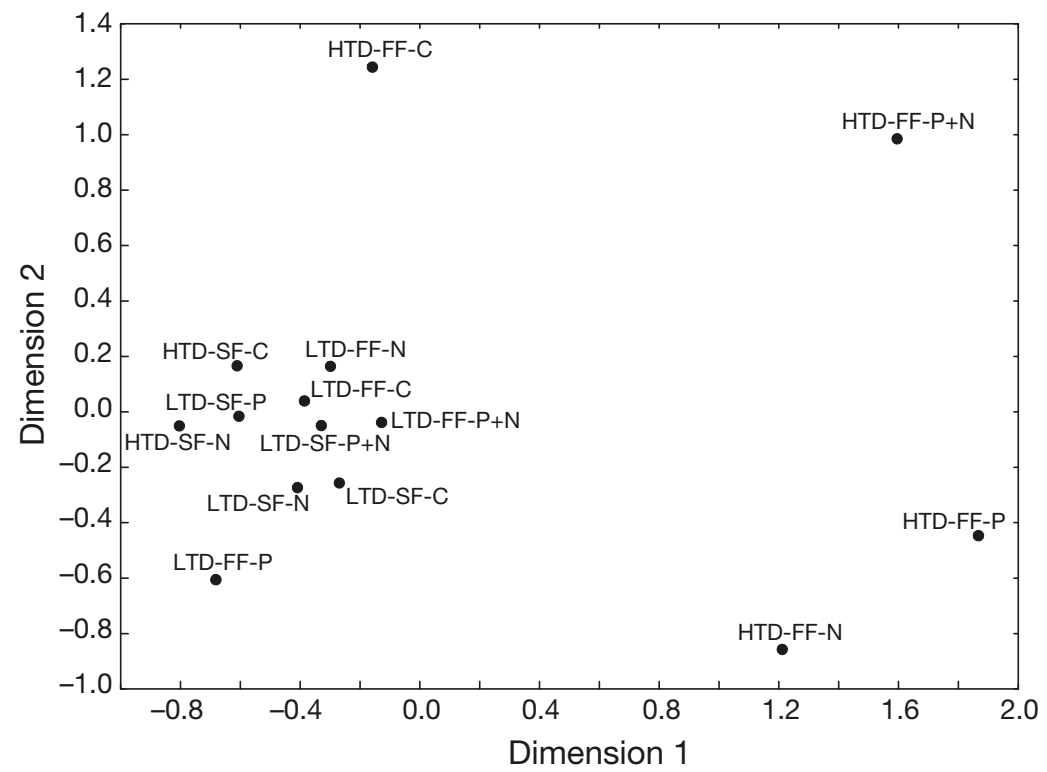

Fig. 6. Non-metric multidimensional scaling ordination of protozoan and micro-metazoan assemblages. Abundance data were averaged and square-root-transformed prior to analysis. Stress $=0.08$. For abbreviations see Fig. 4 
appeared negative (Spearman's $\mathrm{R}<0$ ), but this observation was not significant ( $p>0.05$ ). Regarding LTD sites, the composition of the ciliate community was more similar on substrata placed in SF sites than at FF sites (Fig. 5). Regarding the effect of flow velocity on the abundance of ciliate taxa, peritrichs had an approximately 3-fold greater abundance and a 2-fold greater taxa richness at SF sites. The hymenostomats C. colpoda and Dexiostoma campylum had an approximately 4-fold greater abundance at FF sites, while Euplotes affinis had a 10 -fold greater abundance at SF sites. $C$. glaucoma did not show a flow preference. Statistically significant positive correlations were found between organic matter (AFDW) and the abundance of omnivorous hypotrichs (Spearman's R = $0.52, p=0.0001$ ) and bacterivorous hymenostomats and peritrichs (Spearman's $\mathrm{R}=0.38, \mathrm{p}=0.004$ and $\mathrm{R}=0.46, \mathrm{p}=0.0004$, respectively). Abundances of hypotrichs and peritrichs were also positively correlated with chl a (Spearman's $\mathrm{R}=0.47, \mathrm{p}=$ 0.0002 , and $\mathrm{R}=0.52, \mathrm{p}=0.0001$, respectively).

\section{DISCUSSION}

Results from our experiment demonstrate that both $\mathrm{N}$ and $\mathrm{P}$ are limiting nutrients for autotrophic production of periphyton in the tufa-depositing barrage lake system National Park Plitvice Lakes. Higher calcite deposition apparently decreased the response of autotrophs to $\mathrm{P}$ and $\mathrm{N}$ enrichment, as suggested by the greater chl a concentration and the greater algal response in LTD sites compared to HTD sites. One possible explanation is that $\mathrm{P}$ co-precipitates with calcite, thus limiting the algal uptake of P. Such coprecipitation was hypothesized to impose nutrient limitation on autotrophic production in organosedimentary communities (Elser et al. 2005a). However, we cannot rule out the possible unfavourable effect of calcite precipitation on autotrophs. Rapid burial on accreting surfaces presents problems for algae, and some have evolved adaptations enabling them to exist for long periods on those biotopes (Pentecost 2005).

\section{Effects of flow and nutrient enrichment on tufa deposition}

Differences in tufa deposition between LTD and HTD sites corroborate previous investigations in the Plitvice Lakes (Srdoč et al. 1985, Matoničkin
Kepčija et al 2005, Belančić et al. 2009). The decrease in alkalinity between LTD and HTD sites reflects patterns of calcium carbonate deposition along the system, and this decrease is typical for hydro-chemical downstream evolution of tufadepositing waters (Drysdale et al. 2002). The discrepancy between the lower level of tufa deposition at LTD sites compared to HTD sites, and the apparently higher quantity of $\mathrm{CaCO}_{3}$ in the water at LTD sites, might be explained by the difference in calcite saturation indices between these locations (Kempe \& Emeis 1985, Srdoč et al. 1985). Differences in biologically mediated tufa deposition, either by provision of crystal seeds (Kempe \& Emeis 1985) or through photosynthesis-induced precipitation (Shiraishi et al. 2008), cannot be excluded. Bearing in mind the complexity of tufadepositing systems, the reasons for these observed differences remain to be explained.

Our observation of decreased calcite deposition at the higher velocity sites contradicts the findings of Primc-Habdija et al. (2001) and Pitois et al. (2003). Zaihua et al. (1995) and Chen et al. (2004) also emphasized that FF enhances calcite deposition, but their studies compared flowing and standing water. A possible explanation of the phenomenon observed in our study could be sedimentation of lake-generated calcite crystals, favoured by lowvelocity conditions. The source of particles could also be the resuspension of fine calcite sediments surrounding experimental substrata, as low-velocity areas are characterized by fine sediments (Pitois et al. 2003). Higher AFDW in places of SF, combined with no apparent influence of other tested factors on AFDW, also suggest that sedimentation is an important factor driving periphyton biomass in this investigation.

Surprisingly, nutrient enrichment did not impede calcite deposition. $\mathrm{P}$, which was hypothesized to be a major inhibitor in this investigation, enhanced calcite deposition. Pitois et al. (2003) also recorded peak calcareous deposition in more nutrient-rich sites. A denser autotrophic periphyton matrix developed on enriched substrata and might have led to increased tufa deposition. Cyanobacteria and algae (especially diatoms) are important in the stromatolite building process because they trap and bind calcite crystals and provide substrate for nucleation (Winsborough 2000). Our results suggest that slight enrichment might enhance deposition in nutrient-limited systems, whereas negative effects prevail with higher concentrations of nutrients. There is a need for future investigations into the 
effects of the different nutrient concentrations. The limits of eutrophication that can be withstood by communities before tufa deposition ceases entirely are still not well understood. It is probable that the extent of pollution that is likely to lead to changes in tufa deposition varies between sites (Pentecost \& Whitton 2000).

\section{Effects of flow and nutrient enrichment on algae}

The algal response was increased to some extent in FF conditions, contrary to the findings of Ghosh \& Gaur (1994). The stimulatory effect of current on algae might increase with the concentration of nutrients (Stevenson 1996). Regarding diffusion rates, it seems that FF enabled better diffusion of P from the agar substrate, therefore possibly enabling greater uptake by the algae. Generally, FF seemed to affect the concentration of chl a negatively only at HTD sites, i.e. a combination of high calcite deposition and FF velocity seemed most restrictive. The same conditions increased the rate of breakdown of leaves in the Plitvice Lakes (Belan i et al. 2009), presumably due to coarse tufa fabrics that, combined with FF, led to increased mechanical fragmentation. It is likely that coarse-bladed crystals, typical of higher flow velocities (Pedley 2000), also increased the shear stress for algal periphyton. Sloughing and erosion of biofilm under FF conditions were observed in the experiment of Pedley \& Rogerson (2010), who argue the possibility that there is a threshold velocity above which biofilm colonization is severely restricted.

High calcite deposition and FF velocity might also affect the rate of colonization. If colonization was impeded under these conditions, we cannot conclude that full succession occurred at all sites. Thirty days of exposure was reported to be enough for periphyton colonization in the Plitvice Lakes (Plenković 1989); however, the proportion of cyanobacteria increased in comparison to diatoms after a longer exposure time (Plenković et al. 1989). Exposure times of 2 to $4 \mathrm{wk}$ are used in most periphyton studies involving artificial substrata, with temperature, trophy and current affecting the rate of colonization (Cattaneo \& Amireault 1992). However, the structure of the algal community changed in succession from an initial dominance by $r$-selected diatoms to dominance by crust-forming green algae (Ledger et al 2008); the mesocosm experiment carried out by these authors, using chalk-stream water, indicates the need for an exposure time longer than that used in the present study.

\section{Effects of flow and nutrient enrichment on protozoa and micro-metazoa}

Increased tufa deposition negatively affected both taxa richness and the abundance of protozoa and micro-metazoa. The most limiting conditions for autotrophs, i.e. high tufa deposition and FF, also supported the least number of taxa and the lowest abundance of studied heterotrophs, with few hymenostomats under those conditions. Reduction in the diversity of fauna and flora as a result of calcareous deposition was suggested by Pitois et al. (2001). Also, Rundio (2009) found a lower biomass and diversity of freshwater macroinvertebrates in streams with tufa deposition compared to streams without tufa. Opposing results have also been documented, i.e. higher invertebrate species richness in travertine reaches compared to riffle/run reaches (Marks et al. 2006). These differences might have been driven by different rates of deposition; however, these rates were not measured in the above-mentioned studies, so that no comparison can be made between these studies. High carbonate deposition and encrustation, as in the Plitvice Lakes, create unfavourable conditions for the organisms, burying them alive (Golubić 1969). High sedimentation also inhibits the colonization of some ciliate species, leading to a reduction in the number of ciliate taxa (Risse-Buhl \& Küsel 2009).

Flow velocity influenced the composition of the ciliate community, with certain taxa showing preference for SF or FF. Faster flow probably inhibits the attachment of peritrich ciliates in the early stages of biofilm development (Risse-Buhl \& Küsel 2009). Cyclidium glaucoma is thought to tolerate a broad range of flow velocities due to its small size, enabling it to exploit micro-niches with flow velocities close to zero (Risse-Buhl \& Küsel 2009).

The effects of nutrient enrichment on autotrophs were probably to some extent transmitted to heterotrophs. Nutrient addition led to a drop in the richness of consumer taxa at the FF sites, while there was no effect at the SF sites. This pattern contrasts with the observed increase in chl a concentration. Thus, it may be possible that the denser autotrophic periphyton matrix was the least hospitable for heterotrophs. Battin et al. (2003) reported microstructural differences in biofilms developed under SF vs. FF; SF increased biofilm thickness, sinuosity and fragmentation. Faster flow leads to the increased development of a tightly attached layer of periphyton (Abe et al. 2000), reducing the interstitial space available for colonization of protozoans and smaller metazoans. A concern in our experiment was that, by studying only 
1 sequence of biofilm development, we could not detect the effect of nutrient enrichment on different stages of periphyton development. This effect is not necessarily consistent, i.e. it changes with the age of the periphyton (Norf et al. 2009).

The effect of nutrients on the abundance of heterotrophs was rather weak, and was significant only in the interaction with tufa deposition and flow velocity. Gray et al. (2006) also did not find a significant effect of nutrient addition on higher trophic levels in a detrital community. Some possible taxon-specific responses were detected in the positive correlations between the organic content of periphyton and omnivorous and bacterivorous ciliates. As sedimentation was suggested to play an important role in AFDW patterns, there was probably significant detrital material originating from seston (Sertić Perić et al. 2011). Detritus could lead to a greater abundance of bacteria, which would then be a food resource for bacterivorous and omnivorous ciliates. Omnivorous ciliates showed the highest increase in density after nutrient inputs in a Mediterranean stream (Domènech et al. 2006). The contributions of algivorous ciliate groups (for instance, some Cyrtophorida and Peritrichia species) did not show a clear increase following nutrient enrichment. Hillebrand (2003) reported the increased dominance of relatively large chain-forming and filamentous algal species after the addition of nutrients. Wickham et al. (2004) found an increase in biomass in ciliate groups that are able to graze such algae. The biomass of ciliates was not addressed in our investigation, but it is possible that its response to nutrients would be more pronounced compared to abundance, as in Wickham et al. (2004).

In conclusion, we found a direct bottom-up effect of $\mathrm{N}$ and $\mathrm{P}$ on autotrophic periphyton in a tufa-depositing system. The magnitude of this effect is probably mediated primarily by the extent of tufa deposition. These effects did not cascade appreciably to higher trophic levels.

Acknowledgements. We thank A. Belančić for her immense help during the field work. M. Matoničkin helped us to construct tray samplers. We are very grateful to D. Finn and M. Lacayo-Emery for language corrections and comments. We thank the 3 anonymous reviewers who provided helpful comments that improved the paper. Financial support was provided by The Ministry of Science, Education and Sports of the Republic of Croatia (grant no. 119-0000000-1205).

\section{LITERATURE CITED}

Abe S, Nagumo T, Tanaka J (2000) Effects of current on the development of loosely and tightly attached layers in periphyton communities. Phycol Res 48:261-265
Andrushchyshyn OP, Magnusson AK, Williams DD (2006) Responses of intermittent pond ciliate populations and communities to in situ bottom-up and top-down manipulations. Aquat Microb Ecol 42:293-310

APHA (1985) Standard methods for the examination of water and wastewater, 16th edn. American Public Health Association (APHA), Washington, DC

Battin TJ, Kaplan LA, Newbold JD, Cheng X, Hansen C (2003) Effects of flow velocity on the nascent architecture of stream microbial biofilms. Appl Environ Microbiol 69: 5443-5452

Belančić A, Matoničkin Kepčija R, Miliša M, Plenković Moraj A, Habdija I (2009) Flow velocity effect on leaf litter breakdown in tufa depositing system (Plitvice Lakes, Croatia). Int Rev Hydrobiol 94:391-398

Bernhardt ES, Likens GE (2004) Controls on periphyton biomass in heterotrophic streams. Freshw Biol 49:14-27

Biggs BFJ, Kilroy C (2000) Stream periphyton monitoring manual. National Institute of Water and Atmospheric Research, Christchurch

Biondi B, Biondi R, Meaški H (2010) The conceptual hydrogeological model of the Plitvice Lakes. Geol Croat 62: 195-206

Cattaneo A, Amireault MC (1992) How artificial are artificial substrata for periphyton? J N Am Benthol Soc 11:244-256

Chen J, Zhang DD, Wang S, Xiao T, Huang R (2004) Factors controlling tufa deposition in natural waters at waterfall sites. Sediment Geol 166:353-366

Dodds WK (2006) Eutrophication and trophic state in rivers and streams. Limnol Oceanogr 51:671-680

Dodds WK, Welch EB (2000) Establishing nutrient criteria in streams. J N Am Benthol Soc 19:186-196

> Domènech R, Gaudes A, López-Doval JC, Salvadó H, Muñoz I (2006) Effects of short-term nutrient addition on microfauna density in a Mediterranean stream. Hydrobiologia 568:207-215

Donner J (1965) Ordnung Bdelloidea. Akademie-Verlag, Berlin

Drysdale RN, Taylor MP, Ihlenfeld C (2002) Factors controlling the chemical evolution of travertine-depositing rivers of the Barklly karst, northern Australia. Hydrol Processes 16:2941-2962

- Elser JJ, Schampel JH, Garcia-Pichel F, Wade BD and others (2005a) Effects of P enrichment and grazing snails on modern stromatolitic microbial communities. Freshw Biol 50:1808-1825

Elser JJ, Schampel JH, Kyle M, Watts J and others (2005b) Response of grazing snails to $\mathrm{P}$ enrichment of modern stromatolitic microbial communities. Freshw Biol 50: 1826-1835

Finlay BJ, Esteban GF (1998) Freshwater protozoa: biodiversity and ecological function. Biodivers Conserv 7 : 1163-1186

Foissner W, Blatterer H, Berger H, Kohmann F (1991) Taxonomische und ökologische Revision der Ciliaten des Saprobiensystems - Band I: Cyrtophorida, Oligotrichida, Hypotrichia, Colpodea. Informationsberichte Bayer Landesamt für Wasserwirtschaft 1/91:1-478

Foissner W, Berger H, Kohmann F (1992) Taxonomische und ökologische Revision der Ciliaten des Saprobiensystems-Band II: Peritrichia, Heterotrichida, Odontostomatida. Informationsberichte Bayer Landesamt für Wasserwirtschaft 5/92:1-502

Foissner W, Berger H, Kohmann F (1994) Taxonomische und ökologische Revision der Ciliaten des Saprobiensys- 
tems - Band III: Hymenostomata, Prostomatida, Nassulida. Informationsberichte Bayer Landesamt für Wasserwirtschaft 1/94:1-548

Foissner W, Berger H, Blatterer H, Kohmann F (1995) Taxonomische und ökologische Revision der Ciliaten des Saprobiensystems - Band IV: Gymnostomatea, Loxodes, Suctoria. Informationsberichte Bayer Landesamt für Wasserwirtschaft 1/95:1-540

Golubić S (1969) Cyclic and noncyclic mechanisms in the formation of travertine. Verh Int Ver Limnol 17:956-961

Ghosh M, Gaur JP (1994) Algal periphyton of an unshaded stream in relation to in situ nutrient enrichment and flow velocity. Aquat Bot 47:185-189

Gray SM, Miller TE, Mouquet N, Daufresne T (2006) Nutrient limitation in detritus-based microcosms in Saracenia purpurea. Hydrobiologia 573:173-181

Hillebrand H (2003) Opposing effects of grazing and nutrients on diversity. Oikos 100:592-600

Hillebrand H, Sommer U (2000) Diversity of benthic microalgae in response to colonization time and eutrophication. Aquat Bot 67:221-236

Hillebrand H, Kahlert M, Haglund AL, Berninger UG, Nagel S, Wickham S (2002) Control of microbenthic communities by grazing and nutrient supply. Ecology 83: 2205-2219

Kahl A (1930-1935) Urtiere oder Protozoa I: Wimpertiere oder Ciliata (Infusoria). In: Dahl F (ed) Die Tierwelt Deutschlands. G. Fisher, Jena, p 1-886

Kempe S, Emeis K (1985) Carbonate chemistry and the formation of Plitvice Lakes. In: Degens ET, Kempe S, Herrera R (eds) Transport of carbon and minerals in major world rivers. Mitt Geol-Palaeontol Inst Univ Hamburg, SCOPE/UNEP Sonderband 58, p 351-383

Kock C, Meyer A, Spänhoff B, Meyer E (2006) Tufa deposition in karst streams can enhance the food supply of the grazing caddisfly Melampophylax mucoreus (Limnephilidae). Int Rev Hydrobiol 91:242-249

Koste W (1978) Rotatoria. Die Rädertiere Mitteleuropas. Gebrüder Borntraeger, Berlin

> Ledger ME, Harris RML, Armitage PD, Milner AM (2008) Disturbance frequency influences patch dynamics in stream benthic algal communities. Oecologia 155: 809-819

Lynn DH (2008) The ciliated protozoa. Characterization, classification and guide to the literature, 3rd edn. Springer, Berlin

Marks JC, Parnell R, Carter C, Dinger EC, Haden GA (2006) Interactions between geomorphology and ecosystem processes in travertine streams: implications for decommissioning a dam on Fossil Creek, Arizona. Geomorphology 77:299-307

Matoničkin Kepčija R, Habdija I, Primc-Habdija B, Miliša M (2005) The role of simuliid and trichopterans silk structures in tufa formation during the Holocene of the Plitvice Lakes (Croatia). In: Özkul M, Yağiz S, Jones B (eds) Proc 1st International Symposium on travertine. Kozan Ofset Matbaacilik San. ve Tic, Şti, Ankara, p 96-101

Norf H, Arndt H, Weitere M (2009) Response of biofilmdwelling ciliate communities to planktonic and benthic resource enrichment. Microb Ecol 57:687-700

Nusch EA (1980) Comparison of different methods for chlorophyll and phaeopigment determination. Arch Hydrobiol 14:14-36

Page FC (1991) Nackte Rhizopoda. In: Page FC, Siemensma
FJ (eds) Nackte Rhizopoda und Heliozoa. Gustav Fischer Verlag, Stuttgart, p 1-170

Pedley M (2000) Ambient temperature freshwater microbial tufas. In: Riding RE, Awramik SM (eds) Microbial sediments. Springer-Verlag, Berlin, p 179-186

Pedley HM, Rogerson M (2010) In vitro investigations of the impact of different temperature and flow velocity conditions on tufa microfabric. In: Pedley HM, Rogerson M (eds) Speleothems and tufas: unravelling physical and biological controls. Geological Society Special Publication, Vol 336. Geological Society of London, London, p 193-210 Pentecost A (2005) Travertine. Springer Verlag, Berlin

Pentecost A, Whitton BA (2000) Limestones. In: Whitton BA, Potts M (eds) The ecology of cyanobacteria. Kluwer Academic Publishers, Dordrecht, p 257-279

Pitois F, Jigorel A, Bertru G (2001) Colonization dynamics of an encrusting cyanobacterial mat in a hardwater river (Eaulne, France). Geomicrobiol J 18:139-155

Pitois F, Jigorel A, Bertru G (2003) Development of cyanobacterial build-up and evolution of river bed morphology in the chalk stream Eaulne (Upper-Normandy, France). Biodivers Conserv 12:621-636

> Plant LJ, House WA (2002) Precipitation of calcite in the presence of inorganic P. Colloids Surf A 203:143-153

Plenković A (1989) The influence of artificial substrata on periphyton growth in the aquatic ecosystem of the National Park Plitvice Lakes. Period Biol 91:91

Plenković A, Marčenko E, Srdoč D (1989) Periphyton growth on glass slides in aquatic ecosystem of the National Park Plitvice lakes. Period Biol 91:88-90

Polšak A (1974) Geological aspects of protection of Plitvice lakes (in Croatian). In: Guši B, Markovi M (eds) Plitvice Lakes - man and nature. Publication of Nacionalni park Plitvička jezera, Zagreb, p 23-32

Primc-Habdija B, Habdija I, Plenković-Moraj A (2001) Tufa deposition and periphyton overgrowth as factors affecting the ciliate community on travertine barriers in different flow velocity conditions. Hydrobiologia 457:87-96

Primc-Habdija B, Habdija I, Špoljar M, Matoničkin R (2005) Development of ciliate community on artificial substrata associated with vertical gradient of environmental conditions in a karstic lake. Arch Hydrobiol 164:513-527

> Pusch M, Fiebig D, Brettar I, Eisenmann H and others (1998) The role of micro-organisms in the ecological connectivity of running waters. Freshw Biol 40:453-495

Quinn GP, Keough MJ (2002) Experimental design and data analysis for biologists. Cambridge University Press, Cambridge

Reiss J, Schmid-Araya JM (2008) Existing in plenty: abundance, biomass and diversity of ciliates and meiofauna in small streams. Freshw Biol 53:652-668

Risse-Buhl U, Küsel K (2009) Colonization dynamics of biofilm-associated ciliate morphotypes at different flow velocities. Eur J Protistol 45:64-76

- Rublee PA, Partusch-Talley A (1995) Microfaunal response to fertilization of an arctic tundra stream. Freshw Biol 34: $81-90$

$>$ Rundio DE (2009) Community-habitat relationships in coastal streams in Big Sur, California, USA: Travertine influences macroinvertebrate abundance and community structure. Hydrobiologia 620:91-108

Sabater S, Guasch H, Romaní A, Muňoz I (2000) Stromatolitic communities in Mediterranean streams: adaptations to a changing environment. Biodivers Conserv 9: 379-392 
Sertić Perić MS, Miliša M, Matoničkin Kepčija R, PrimcHabdija B, Habdija I (2011) Seasonal and fine-scale spatial drift patterns in a tufa-depositing barrage hydrosystem. Fundament Appl Limnol 178:131-145

Shiraishi F, Reimer A, Bissett A, de Beer D, Arp G (2008) Microbial effects on biofilm calcification, ambient water chemistry and stable isotope records in a highly supersaturated setting (Westerhofer Bach, Germany). Palaeogeogr Palaeoclimatol Palaeoecol 262:91-106

Soininen J (2004) Assessing the current related heterogeneity and diversity patterns of benthic diatom communities in a turbid and a clear water river. Aquat Ecol 38: 495-501

Srdoč D, Horvatinčić N, Obelić B, Krajcar I, Sliepčević A (1985) Calcite depostition processes in karstwaters with special emphasis on the Plitvice Lakes, Yugoslavia. Carsus Iugoslaviae 11:101-204 (in Croatian with English Abstract)

Stevenson RJ (1996) The stimulation and drag of current. In: Stevenson RJ, Bothwell ML, Lowe RL (eds) Algal ecol-

Editorial responsibility: Tom Battin,

Vienna, Austria ogy: freshwater benthic ecosystems. Academic Press, San Diego, CA, p 321-341

Tank JL, Dodds WK (2003) Nutrient limitation of epilithic and epixylic biofilms in ten North American streams. Freshw Biol 48:1031-1049

Tank JL, Bernot MJ, Rosi-Marshall EJ (2006) Nitrogen limitation and uptake. In: Hauer FR, Lamberti GA (eds) Methods in stream ecology, 2nd edn. Academic Press, San Diego, CA, p 213-238

- Wickham SA, Nagel S, Hillebrand H (2004) Control of epibenthic ciliate communities by grazers and nutrients. Aquat Microb Ecol 35:153-162

Winsborough BM (2000) Diatoms and benthic microbial carbonates. In: Riding RE, Awramik SM (eds) Microbial sediments. Springer-Verlag, Berlin, p 76-83

Zaihua L, Svensson U, Dreybrodt W, Daoxian Y, Buhmann D (1995) Hydrodynamic control of inorganic precipitation in Huanlong Ravine, China: field measurements and theoretical prediction of deposition rates. Geochim Cosmochim Acta 59:3087-3097

Submitted: February 25, 2011; Accepted: October 19, 2011 Proofs received from author(s): December 1, 2011 